\title{
Implementasi Sistem Pencarian Wisata Menggunakan Tour Talk Share (TTS) Berbasis Android Pada Provinsi Sulawesi Selatan
}

\author{
Rismayani $^{*}$, Sri Wahyuni' ${ }^{2}$, Madyana Patasik ${ }^{3}$, Iskandar ${ }^{4}$, Sitti Asnany \\ 1)Program Studi Rekayasa Perangkat Lunak, STMIK Dipanegara Makassar \\ 2,3)Program Studi Teknik Informatika, STMIK Dipanegara Makassar \\ 4,5)Program Studi Sistem Informasi, STMIK Dipanegara Makassar \\ Jl. Perintis Kemerdekaan Km.9 Makassar, Makassar, Indonesia 90000 \\ *email: rismayani@dipanegara.ac.id
}

(Naskah masuk: 8 September 2020; diterima untuk diterbitkan: 2 April 2021)

\begin{abstract}
ABSTRAK - Sulawesi Selatan adalah sebuah provinsi di Indonesia yang terletak di bagian selatan Sulawesi dengan ibu kotanya adalah Makassar yang memiliki banyak tempat - tempat wisata yang sangat menarik. Selama ini telah banyak aplikasi ataupun halaman website yang memperkenalkan tempat - tempat wisata di provinsi Sulawesi Selatan, namun hanya dapat menampilkan penjelasan tempat wisata dan lokasi saja dalam bentuk maps. Adapun permasalahan dalam penelitian ini adalah terdapat beberapa sistem yang digunakan namun masih terbatasnya ruang lingkup wisata yang hanya ditujukan pada satu kabupaten atau kota madya saja, kemudian bagaimana memanfaatkan fitur Chatting, Sharing, dan Video dalam aplikasi pencarian wisata, selanjutnya bagaimana membantu para wisatawan untuk saling berkomunikasi dalam melakukan perjalanan wisata yang ada di provinsi Sulawesi Selatan dan bagaimana merancang sistem pencarian wisata menggunakan Tour, Talk, Share berbasis mobile android di provinsi Sulawesi Selatan. Adapun tujuan dari penelitian ini adalah untuk merancang sistem pencarian objek wisata pada provinsi Sulawesi Selatan, membuat sebuah sistem dengan penambahan fitur Chatting, fitur sharing, dan fitur seperti kemampuan menonton video yang berguna dalam pencarian objek wisata dan dapat saling berkomunikasi serta untuk mengimplementasikan sistem Tour, Talk, Share dengan teknologi android dalam perjalanan wisata untuk membatu wisatawan. Metode dan teknologi yang digunakan pada penelitian ini adalah mobile android, mobile adalah sebuah benda yang berteknologi tinggi dan dapat bergerak tanpa menggunakan kabel dan android adalah sistem operasi berbasis Linux yang dirancang untuk perangkat bergerak layar sentuh seperti telepon pintar dan komputer tablet. Adapun hasil penelitian adalah dengan mengimplementasikan sistem wisata Tour Talk Share (TTS) berbasis mobile android pada provinsi Sulawesi Selatan maka dapat membantu para wisatawan untuk mendapatkan informasi wisata yang lebih detail dengan fitur yang lebih lengkap.
\end{abstract}

Kata Kunci - Tour Talk Share (TTS), Sistem Pencarian, Wisata, Android

\section{Implementation of a Tourism Search System Using an Android-Based Tour Talk Share (TTS) in South Sulawesi Province}

\begin{abstract}
South Sulawesi is one of the provinces in Indonesia, located in the southern part of Sulawesi with the capital Makassar city which has many very interesting tourist attractions. So far, there have been many applications or website pages that introduce tourist attractions in South Sulawesi province, but they can only display an explanation of tourist attractions and their locations in the form of maps. The problem in this study is that there are several systems used but the scope of tourism is still limited, namely only aimed at one district or city, then how to use the Chat, Sharing, and Video features in the travel search application, Furthermore, how to help tourists communicate with each other in traveling in South Sulawesi province and how to design a tourism search system using Tour, Talk, Share based on android mobile in South Sulawesi province. The aim of this research is to design a tourist attraction search system in the province of South Sulawesi, create a system with the addition of chat features, sharing features, and features such as the ability to watch videos that are useful in finding tourist objects and being able to communicate with each other and implementing the tour system. Talk, share with android technology on your way to help tourists. The method and technology used in this study are mobile android, mobile is an object that is high-tech and can move without using
\end{abstract}




\section{Rismayani, S Wahyuni, M Patasik, Iskandar \& S Asnany}

Komputika: Jurnal Sistem Komputer, Vol. 10, No. 1, April 2021

cables and android is a linux-based operating system designed for touch screen mobile devices such as smartphones and tablet computers. The result of this research is that the application of the Android-based Tour Talk Share (TTS) tourism system in South Sulawesi Province can help tourists get more detailed tourist information with more complete features.

Keywords - Tour Talk Share (TTS), Searching System, Travel, Android

\section{Pendahuluan}

Sulawesi Selatan adalah sebuah provinsi di Indonesia yang terletak di bagian selatan Sulawesi dengan ibu kotanya adalah Makassar yang memiliki banyak tempat - tempat wisata yang sangat menarik. Dengan adanya keberadaan Aplikasi dan Website memang menjadi andalan dalam melakukan penyebaranya informasi terkait dengan sebuah destinasi pariwisata. Selama ini sistem yang digunakan tersebut masih terdapat beberapa fitur yang belum mendukung diantaranya, terbatasnya ruang lingkup wisata yang hanya ditujukan pada satu kabupaten atau kota madya saja, informasi tempat wisata berupa video, dan fitur yang mendukung para wisatawan agar bisa saling berkomunikasi. Dengan memanfaatkan layanan Maps, Chatting, dan Sharing, maka penulis membuat sebuah aplikasi yang tidak hanya berfungsi untuk mencari lokasi serta memberikan informasi mengenai objek wisata tetapi juga dilengkapi dengan berbagai fitur seperti kemampuan menonton video dan mengupload foto yang membantu para wisatawan untuk saling berkomunikasi dalam melakukan perjalanan wisata yang ada di provinsi Sulawesi Selatan. Aplikasi mobile phone khususnya sistem operasi android berkembang dengan pesat. Android sebagai sistem operasi yang bersifat terbuka atau biasa di sebut dengan 'open source' membuat para pengembang aplikasi berlomba-lomba merancang suatu aplikasi. Dengan demikian pertumbuhan aplikasi android mobile phone semakin hari semakin pesat. Penggunaan Maps juga sebagai aplikasi mobile phone yang menyediakan informasi mengenai lokasi sekaligus penunjuk arah yang diciptakan langsung oleh Google masih belum memenuhi kebutuhan wisatawan dalam informasi dan lokasi objek wisata di Sulawesi Selatan karena Maps tidak memberikan informasi khusus objek wisata yang ada di Sulawesi Selatan.

Adapun masalah dalam penelitian adalah selama ini terdapat beberapa sistem yang digunakan namun masih terbatasnya ruang lingkup wisata yang hanya ditujukan pada satu kabupaten atau kota madya saja, bagaimana memanfaatkan fitur Chatting, Sharing, dan Video dalam aplikasi pencarian wisata di provinsi Sulawesi Selatan, bagaimana membantu para wisatawan untuk saling berkomunikasi dalam melakukan perjalanan wisata yang ada di provinsi Sulawesi Selatan dan bagaimana mengimplementasikan sistem wisata Tour Talk Share (TTS) berbasis android di provinsi Sulawesi Selatan. Kontribusi penelitian adalah membuat sebuat sistem yang dapat membantu para wisatan dalam mendapatkan informasi lokasi wisata yang lebih efisien dengan di dukung adanya penambahan fitur Tour Talk dan Share dari para wisatawan yang pernah berkunjung ke lokasi wisata tersebut.

Tujuan dari penelitian adalah untuk membuat sistem pencarian objek wisata pada keseluruhan provinsi Sulawesi Selatan dengan tampilan yang lebih menarik, membuat sebuah sistem dengan memanfaatkan penambahan fitur Chatting, fitur sharing, dan fitur seperti kemampuan menonton video yang berguna dalam pencarian objek wisata di provinsi Sulawesi Selatan, membuat sistem yang tidak hanya untuk pencarian objek wisata tapi juga mudah untuk saling berkomunikasi saat berwisata di provinsi Sulawesi Selatan dan untuk mengimplementasikan sistem pencarian wisata menggunakan Tour Talk Share (TTS) berbasis android di provinsi Sulawesi Selatan.

Manfaat dari penelitan yang dilakukan adalah dapat membantu wisatawan untuk melakukan pencarian objek wisata yang ada pada provinsi Sulawesi Selatan dengan tampilan yang lebih menarik, membantu wisatawan dalam memperoleh informasi tempat wisata di provinsi Sulawesi Selatan dengan adanya penambahan fitur Chatting, fitur sharing serta fitir yang memiliki kemampuan menonton video tempat wisata dan membantu para wisatawan dalam melakukan pencarian wisata dengan melakukan komunikasi antar wisatawan yang tersedia pada fitur sitem pencarian wisata di provinsi Sulawesi Selatan serta dapat mengimplementasikan Tour Talk Share (TTS).

Adapun beberapa pustaka yang terkait dalam mendukung teori dalam penelitian sebagai berikut :

Wisata adalah bepergian secara bersama-sama dengan tujuan untuk bersenang-senang, menambah pengetahuan, dan lain-lain. Selain itu juga dapat diartikan sebagai bertamasya atau piknik[1]. 


\section{Rismayani, S Wahyuni, M Patasik, Iskandar \& S Asnany}

Komputika: Jurnal Sistem Komputer, Vol. 10, No. 1, April 2021

Periwisata Adalah Keseluruhan hubungan dan gejala-gejala yang timbul dari adanya orang asing dan perjalanannya itu tidak untuk bertempat tinggal menetapdan tidak ada hubungan dengan kegiatan untuk mencari nafkah.Sehingga dalam melakukan perjalanannya tersebut hanya mencari hal-hal yang sesuai dengan keinginan dan kebutuhannya[2].

Adapun beberapa jenis wisata sebagai berikut[3] :

1. Wisata Alam Wisata alam adalah kegiatan perjalanan yang dilakukan oleh seseorang atau kelompok dengan mengunjungi tempat tertentu untuk tujuan rekreasi, pengembangan pribadi, atau mempelajari daya tarik alam dengan memanfaatkan potensi sumberdaya alam, baik itu alami maupun budidaya.

2. Wisata Kuliner Wisata kuliner adalah suatu perjalanan yang di dalamnya meliputi kegiatan mengonsumsi makanan lokal dari suatu daerah;.

3. Wisata Bahari Wisata Bahari adalah seluruh kegiatan yang bersifat rekreasi yang aktifitasnya dilakukan pada media kelautan atau bahari dan meliputi daerah pantai, pulau-pulau sekitarnya, serta kawasan lautan dalam pengertian pada permukaannya, dalamnya, ataupun pada dasarnya.

4. Wisata Edukasi Wisata edukasi merupakan suatu program yang menggabungkan unsur kegiatan wisata dengan muatan pendidikan didalamnya..

Selanjutnya yang dimaksud search engine atau mesin pencari adalah sebuah sistem software atau sebuah aplikasi yang didesain dan disediakan oleh suatu badan komersial tertentu dan dibuat dengan tujuan untuk memudahkan pengguna internet mencari berbagai informasi di internet[5].

Tour adalah perjalanan wisata, yang memiliki ciriciri suatu perjalanan, tetapi perjalanan wisata mempunyai ciri-ciri khas yang memperlihatkan warna kegiatan wisata, kemudian Talk atau talking adalahpembicaraan atau komunikasi sesama antar pengguna dan share adalah sebuah kata bahasa Inggris yang artinya berbagi[6].

Platform yang digunakan adalah android, nndroid merupakan sistem operasi berbasis Linux yang digunakan untuk perangkat mobile seperti smartphone[7]. Sejalan dengan hal tersebut, Android adalah sistem operasi untuk perangkat mobile berbasis Linux yang mencakup sistem operasi, middleware, dan aplikasi.

Adapun beberapa tempat wisata yang ada di provinsi Sulawesi Selatan yaitu :
Tabel 1. Daftar Tempat Wisata Provinsi Sulawesi Selatan[4]

\begin{tabular}{|c|c|c|}
\hline No & Objek Wisata & Lokasi \\
\hline \multirow[t]{2}{*}{1} & Taman Nasional & Kabupaten \\
\hline & Bantimurung & Maros \\
\hline \multirow[t]{2}{*}{2} & Pantai Losari & Kota \\
\hline & & Makassar \\
\hline \multirow[t]{2}{*}{3} & Benteng Rotterdam & Kota \\
\hline & & Makassar \\
\hline \multirow[t]{2}{*}{4} & Wisata Taman Laut Taka & Kota Benteng \\
\hline & Bone Rate & $\begin{array}{l}\text { Kepulauan } \\
\text { Selayar }\end{array}$ \\
\hline 5 & Kebun Teh Malino & Malino \\
\hline \multirow[t]{2}{*}{6} & Tanjung Bira & Kabupaten \\
\hline & & Bulukumba \\
\hline \multirow[t]{2}{*}{7} & Benteng Somba Opu & Kabupaten \\
\hline & & Gowa \\
\hline \multirow[t]{2}{*}{8} & Wisata Bahari Samalona & Pulau \\
\hline & & Samalona \\
\hline \multirow[t]{2}{*}{9} & Pegunungan Karst & Kabupaten \\
\hline & (Kapur) & Maros \\
\hline \multirow[t]{2}{*}{10} & Pulau Kayangan & Pulau \\
\hline & & Kayangan \\
\hline \multirow[t]{2}{*}{11} & Desa Kete Kesu & Kabupaten \\
\hline & & Tana Toraja \\
\hline 12 & Lemo/Londa & Makale Tana \\
\hline \multirow{2}{*}{13} & & $\begin{array}{l}\text { Toraja } \\
\text { Kabupaten }\end{array}$ \\
\hline & $\begin{array}{l}\text { Wisata Budaya Rambu } \\
\text { Solo' }\end{array}$ & $\begin{array}{l}\text { Kabupaten } \\
\text { Tana Toraja }\end{array}$ \\
\hline
\end{tabular}

Adapun beberapa penelitian yang terkait adalah penelitian yang membuat sebuah aplikasi android sistem informasi geografis keberadaan dan pencarian objek wisata pulau Nias untuk membantu para wisatawan yang melakukan liburan di Pulau Nias[8]. Selanjutnya penelitian yang menerapkan web service dalam pencarian obyek wisata berbasis android dan menerapkan arsitektur REST yang dapat diakses berbagai macam jenis client baik itu berupa web maupun desktop dalam pencarian objek wisata[9]. Selanjutnya penelitian yang mengimplementasi chatbot informasi pariwisata di Bali menggunakan Fulltext Search Boolean Mode[10], kemudian membuat aplikasi yang berbasis android untuk wisata di ibu kota Jakarta yang dimana aplikasi tersebut dapat mengakses google map untuk menapilkan lokasi wisata yang dicari dan lokasi pengguna serta tempat wisata yang akan dipilih oleh pengguna[11]. Penelitian yang merancang sistem informasi geografis bertujuan untuk memberikan kemudahan dan kecepatan kepada masyarakat dalam memperoleh informasi mengenai Objek Wisata Alam di Propinsi Sumatera Utara[12]. Selanjutnya penelitian yang membahas pembuatan sistem informasi geografis untuk pencarian lokasi kuliner terdekat kota Mataram 


\section{Rismayani, S Wahyuni, M Patasik, Iskandar \& S Asnany}

Komputika: Jurnal Sistem Komputer, Vol. 10, No. 1, April 2021

yang memudahkan wisatawan untuk mengetahui pemetaan lokasi wisata kuliner. Sistem informasi geografis dirancang berbasis web dengan menggunakan konsep MVC[13] yang memberikan solusi dalam mencari lokasi wisata serta membantu mengenalkan berbagai macam objek wisata yang ada di Kabupaten Jember[14]. Kemudian penelitian yang mengembangkan Sistem Informasi pencarian tempat wisata bersejarah di Kota Malang dan navigasi rute menuju tempat wisata tersebut berbasis Android[15] yang mengembangkan aplikasi yang dapat mempermudah konsumen menemukan informasi tempat kuliner sesuai dengan budget dengan meggunakan teknologi GPS pada samartphone[16]. Penelitian yang membangun Sistem Informasi Geografis berbasis Android dengan menggunakan Algoritma Dijkstra, yang dapat membantu wisatawan dari luar wilayah Kota Sumenep dalam menampilkan rute dari satu tempat wisata ke tempat wisata lainnya[17]. Selanjutnya penelitian yang merancang sistem informasi geografis (SIG) berbasis web yang dapat membantu wisatawan dalam mencari lokasi wisata di Kota Tangerang dengan mudah dan tepat[18] dan penelitian yang memberikan solusi permasalahan pencarian lokasi kuliner di Tasikmalaya dengan merancang Website Mobile kuliner menggunakan PHP dan MySQL dan metode LBS (Location Based Service)[19]. Kemudian penelitian yang merancang halaman website berupa website Temu Lampung yang bertujuan untuk membantu dan memudahkan turis yang berkunjung dari berbagai macam daerah agar dapat lebih mudah melakukan pencarian tempat wisata serta pemandu wisata (tour guide) di Lampung[20]. Dalam membuat sistem berbasis android berfungsi sebagai navigasi ke Lokasi wisata pada kabupaten Timor Tengah Selatan yang ditampilkan dalam peta berupa penanda titik lokasi[21]. Selanjutnya penelitian yang membahas mengenai pembuatan sistem informasi pencarian lokasi di kabupaten Maros menggunakan Google Maps API[22]. Kemudian penelitian yang membahas mengenai pencarian rute angkutan umum dikota Makassar yang menggunakan teknologi Google Maps API dan menggunakan metode DFS[23]. Dari semua penelitian terkait yang telah dirujuk perbedaan penelitian yang dilakukan oleh penulis adalah penulis menambahkan fitur Tour Talk dan Share, pada hasil penelitian pula adanya penambahan fitur Chatting grup atau forum.

\section{METODE DAN BAHAN}

Adapun beberapa metode dan bahan yang digunakan dala penelitian ini sebagai berikut:

\section{A. Lokasi Penelitian}

Lokasi penelitian terdapat di Dinas Pariwisata dan Kebudayaan Provinsi Slawesi Selatan dengan objek penelitian tempat-tempat wisata yang ada di Provinsi Sulawesi Selatan.

\section{B. Alat Penelitian}

a. Perangkat Keras :

1. Laptop Acer VX15 Spesifikasi :

a. Processor Intel i7 Gen 7

b. GPU Nvidia Gefore GTX 1050

c. Ram 16GB DDR4 2. Mouse Logitec K150

3. Smartphone Android Xiaomi Mi 5X Spesifikasi :

a. Qualkomm Snapdragon 625

b. Gpu Andreno 506

c. Ram 4 Gb Internal 32 GB

b. Perangkat Lunak :

1. Windows 10 pro

2. Microsoft Word 2010

3. Android Studio 2017

4. Visual Studio 2016

5. StarUML

6. Mozilla Firefox

7. Os 7.1 Nougat

\section{Bahan Penelitian}

a. Data - data Nama Tempat Wisata Provinsi

Sulawesi Selatan.

b. Data Lokasi dan informasi Tempat Wisata

Provinsi Sulawesi Selatan.

c. Video Tempat Wisata yang ada di Provinsi

Sulawesi Selatan.

\section{Tahapan Penelitian}

Adapun tahapan dari penelitian sebagai berikut :

1. Pengumpulan Data : mengumpulkan informasi dari lokasi penelitian.

2. Analisi Sistem : penguraian dari suatu sistem informasi yang utuh kedalam bagian-bagian komponennya dengan maksud untuk mengidentifikasi dan mengevaluasi permasalahan, kesempatan, hambatan yang terjadi dan kebutuhan yang diharapkan sehingga dapat diusulkan perbaikannya.

3. Merancang Sistem : proses merancang sistem sebelum membuat coding dari sistem pencarian wisata yang dibuat.

4. Pembuatan sistem informasi : merupakan strategi untuk memecahkan masalah dan mengembangkan solusi terbaik bagi permasalahan sistem pencarian wisata.

5. Pengujian Sistem : mengetahui cara kerja dari aplikasi yang dirancang secara terperinci sesuai spesifikasi dan menilai apakah setiap fungsi atau prosedur yang dirancang sudah bebas dari kesalahan logika sistem pencarian wisata.

6. Implementasi : yaitu penerapan pemodelan sistem yang telah dibuat untuk diaplikasikan ke pengguna yaitu para wisatawan yang 


\section{Rismayani, S Wahyuni, M Patasik, Iskandar \& S Asnany}

Komputika: Jurnal Sistem Komputer, Vol. 10, No. 1, April 2021

berkunjung ke tempat wisata yang ada di provinsi Sulawesi Selatan.

\section{E. Arsitektur Sistem}

Adapun arsitektur dalam sistem yang dibangun sebagai berikut :

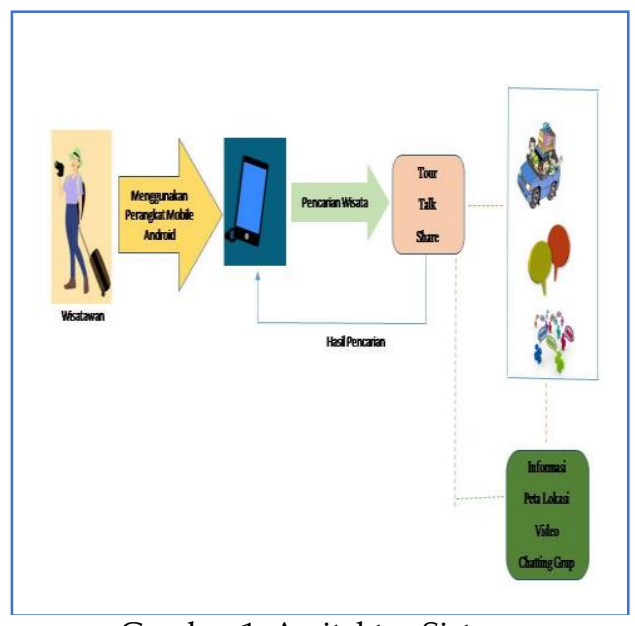

Gambar 1. Arsitektur Sistem

Gambar 1 merupakan rancangan dari astitektur sistem yang dimana wisatawan menggunakan perangkat mobile android untuk melakukan pencarian pada sistem wisata yang menggunakan model TTS ( Tour Talk Share ) yang mana dalam sistem selain dapat melihat informasi wisata dan lokasi wisata, para wisatawan juga dapat melakukan Chatting grup dan video beberapa tempat wisata yang ada di provinsi Sulawesi Selatan.

\section{HASIL DAN PEMBAHASAN}

\section{A. Gambaran Umum Sistem}

Adapun gambaran umum dari sistem sebagai berikut :

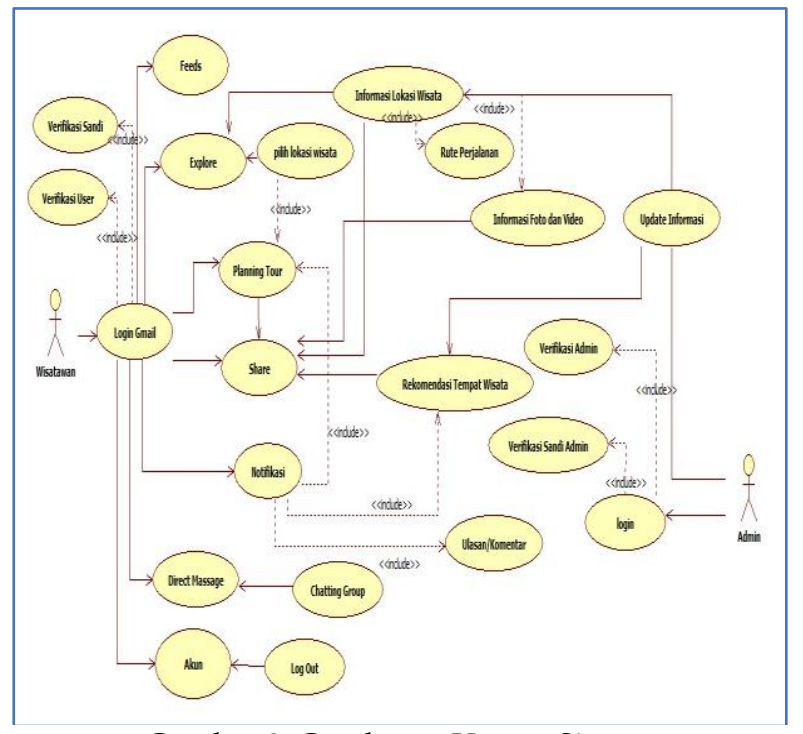

Gambar 2. Gambaran Umum Sistem
Gambar 2 menjelaskan beberapa fungsi yang berhubungan dengan wisatawan tersebut. Wisatawan pertama-tama me-login dengan akun google untuk masuk ke aplikasi, kemudian wisatawan memilih objek wisata dari tiap kabupaten yang dipilih. Selanjutnya wisatawan memilih objek wisata dan mendapatkan posisi lokasi objek wisata yang di pilih, objek wisata yang di dapatkan dapat dimasukkan dalam planning sebagai perencanaan sebelum melakukan perjalanan wisata. Setalah wisatawan mendapatkan objek wisata maka akan muncul posisi lokasi pada peta. Selanjutnya wisatawan dapat melihati nformasi objek wisata yang telah di pilih. Wisatawan juga dapat sharing posisi objek wisata dan dapat mengupload foto pada aplikasi.

\section{B. Tampilan Sistem}

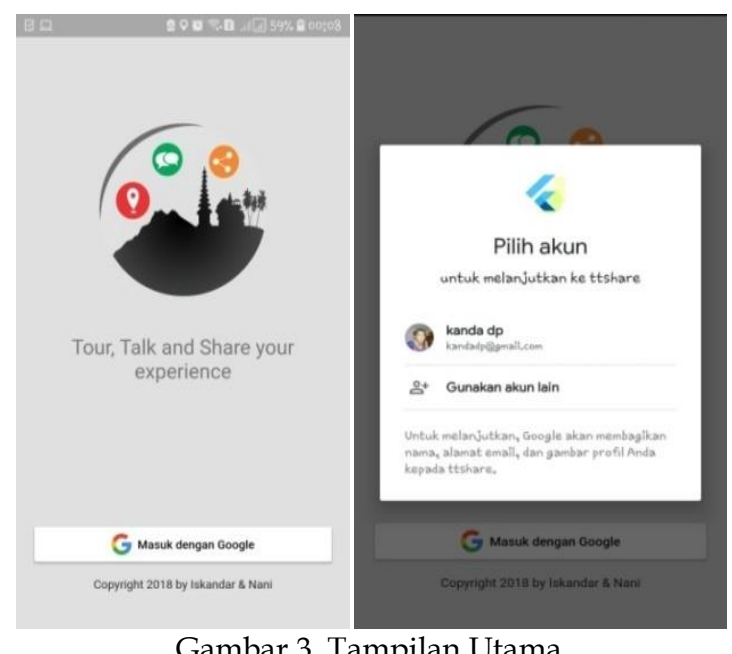

Gambar 3 merupakan tampilan utama dari sistem, yang dimana langkah awal untuk masuk ke sistem adalah dengan memasukkan alamat google mail yang telah terdaftar terdaftar, untuk login kedalam sistem dan mengklik masuk dengan akun Google seperti.

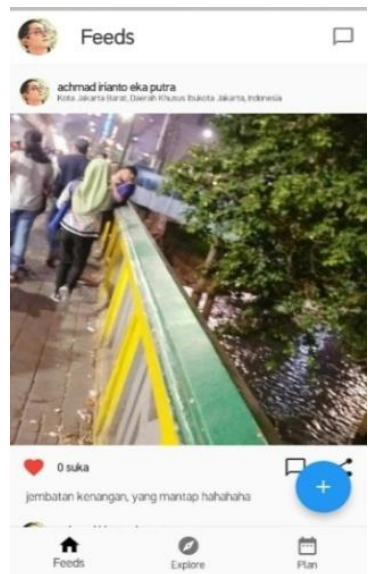

Gambar 5. Menu Feeds 


\section{Rismayani, S Wahyuni, M Patasik, Iskandar \& S Asnany}

Komputika: Jurnal Sistem Komputer, Vol. 10, No. 1, April 2021

Gambar 5 memperlihatkan tombol dengan icon home berfungsi untuk menampilkan feed/postingan dari semua user, tombol dengan icon kompas berfungsi untuk menampilkan explorer/daftar objek wisata yang ada di dalam aplikasi, tombol dengan icon kalender berfungsi menampilkan planning atau perencanaan berwisata dan tombol dengan icon akun menampilkan akun yang sedang di pakai user.

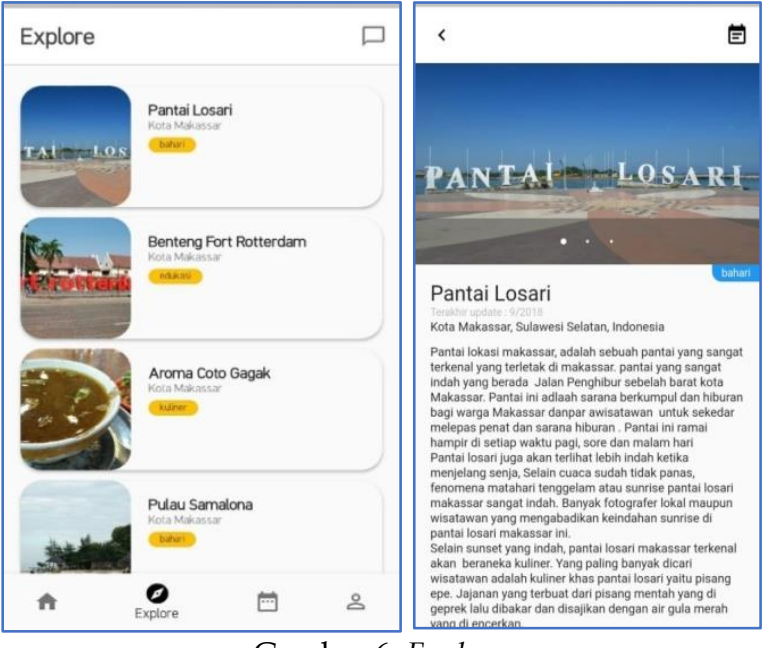

Gambar 6. Explore

Gambar 6 tampilan Explore, Explore tersebut digunakan untuk pencarian wisata disetiap kabupaten yang ada di Sulawesi Selatan, dan pada list explore kabupaten sistem akan menampilakan objek wisata pada setiap kabupaten dari wisata yang telah dipilih pada salah satu list explore dari wisata di provinsi Sulawesi Selatan.

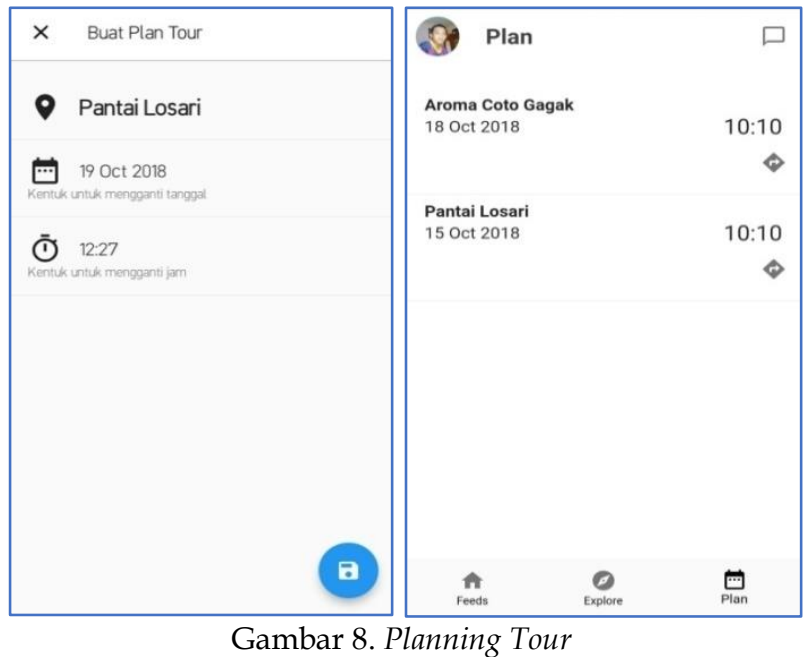

Gambar 8 merupakan penginputan atau membuat planning tour yang akan dilakukan wisatawan jika akan berkunjung ke Sulawesi Selatan dan menampilkan list planning tour yang akan dikunjungi oleh para wisatawan.

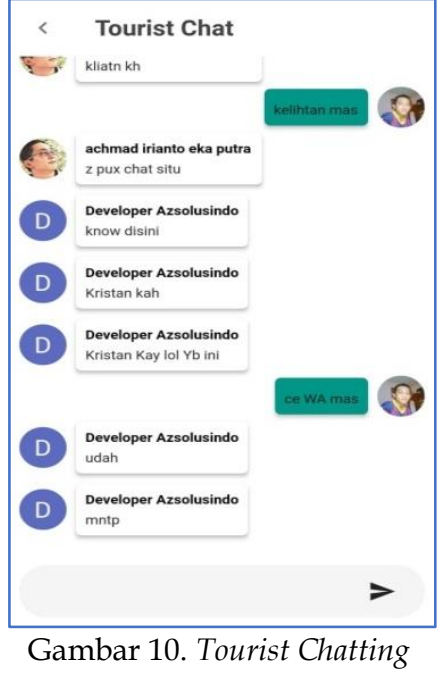

Gambar 10 merupakan menu Chatting yang digunakan untuk membantu para wisatawan untuk saling berkomunikasi dan saling bertukar informasi mengenai objek wisata dengan Chatting grup.

\section{Pengujian}

Adapun pengujian yang dilakukan untuk menguji fongsional sistem adalah menggunakan pengujian Blacbox sebagai berikut :

Tabel 2. Pengujian Blackbox

\begin{tabular}{|c|c|c|c|}
\hline No & Skenario & Hasil & Kesimpulan \\
\hline 1 & Login & $\begin{array}{l}\text { Sistem akan } \\
\text { menampilkan } \\
\text { menu log in }\end{array}$ & Valid \\
\hline 2 & Feeds & $\begin{array}{l}\text { User dapat } \\
\text { melihat hasil } \\
\text { postingan } \\
\text { yang telah di } \\
\text { upload }\end{array}$ & Valid \\
\hline 3 & Explore & $\begin{array}{l}\text { User dapat } \\
\text { melihat daftar } \\
\text { objek wisata } \\
\text { dalam bentuk } \\
\text { list dan } \\
\text { penjelasannya }\end{array}$ & Valid \\
\hline 4 & Planning & $\begin{array}{l}\text { Sistem dapat } \\
\text { menampilkan } \\
\text { menu planning } \\
\text { pada user }\end{array}$ & Valid \\
\hline 5 & Chatting & $\begin{array}{l}\text { User dapat } \\
\text { bekomunikasi } \\
\text { dengan } \\
\text { sesama } \\
\text { pengguna }\end{array}$ & Valid \\
\hline
\end{tabular}

Selanjutnya dilakukan pengujian kuesioner untuk mengetahui manfaat dari sistem yang telah dibuat, pertanyaan kuesioner terdiri dari 10 soal dengan jumlah responden 50, derajat penilaian sangat 


\section{Rismayani, S Wahyuni, M Patasik, Iskandar \& S Asnany}

Komputika: Jurnal Sistem Komputer, Vol. 10, No. 1, April 2021

bermanfaat bernilai 4 , bermanfaat bernilai 3, tidak bermanfaat bernilai 2 dan sangat tidak bermanfaat bernilai 1.

Tabel 3. Hasil Kuesioner

\begin{tabular}{clcc}
\hline No & \multicolumn{1}{c}{ Indikator } & Nilai & Hasil \\
\hline 1 & Sangat & 4 & $13 \%$ \\
& $\begin{array}{l}\text { Bermanfaat } \\
2\end{array}$ & & \\
3 & Bermanfaat & 3 & $81 \%$ \\
& $\begin{array}{l}\text { Tidak } \\
\text { Bermanfaat }\end{array}$ & 2 & $6 \%$ \\
4 & $\begin{array}{l}\text { Sangat Tidak } \\
\text { Bermanfaat }\end{array}$ & 1 & $0 \%$ \\
\hline
\end{tabular}

Pada tabel 3 memperlihatkan hasil dari kuesioner yang menyatakan sangat bermanfaat 13\%, bermanfaat $81 \%$, tidak bermafaat $6 \%$ dan sangat tidak bermanfaat $0 \%$.

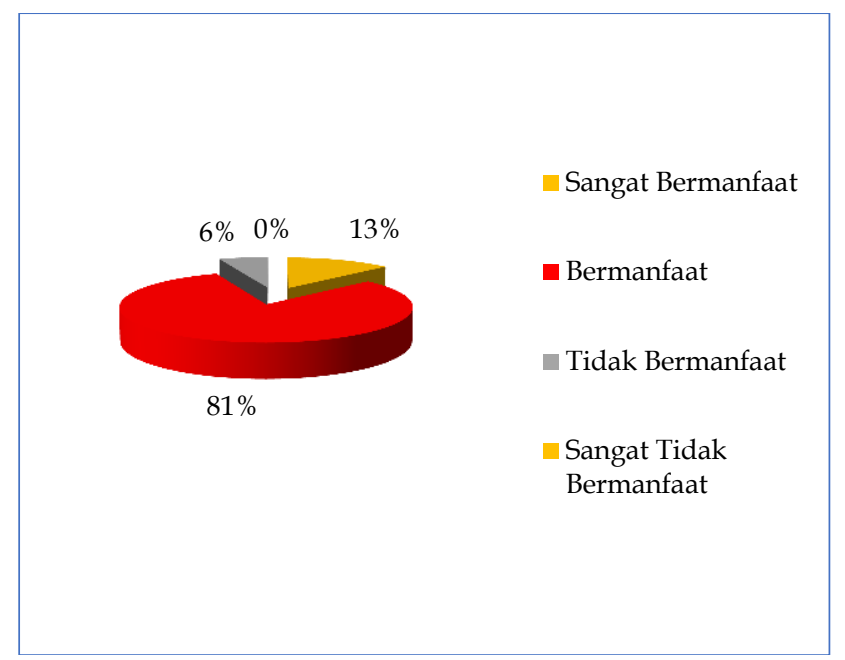

Gambar 10. Diagram Hasil Persentase Kuesioner

\section{KESIMPULAN}

Kesimpulan penelitian adalah dibangun sebuah sistem pencarian wisata di provinsi Sulawesi Selatan dengan menambahkan fitur Tour, Talk dan share, dengan mengimplementasikan sistem wisata Tour Talk Share (TTS) berbasis mobile android pada provinsi Sulawesi Selatan maka dapat membantu para wisatawan untuk mendapatkan informasi wisata yang lebih detail dengan fitur yang lebih lengkap dan bermanfaat bagi para wisatawan yang berdasarkan hasil kuesioner menyatakan sangat bermanfaat $13 \%$, bermanfaat $81 \%$, tidak bermafaat $6 \%$ dan sangat tidak bermanfaat $0 \%$. Berdasarkan pengujian fungsional test factor pada sistem pencarian wisata ditemukan hasil yang Valid. Sistem yang dibangun tidak menggantikan sistem-sistem yang sebelumnya pernah ada namun sistem yang dibangun menjadi alternatif buat para wisatawan.
Sistem yang dibangun menjadi guide bagi wisatawan yang akan dan mau berwisata ke provinsi Sulawesi Selatan.

Saran untuk pengembangan penelitian adalah untuk sistem dapat menggunakan dua bahasa yaitu bahasa indonesia dan inggris, sehingga sistem tersebut tidak hanya dapat digunakan untuk wisatawan lokal namun juga dapat digunakan untuk wisatawan internasional.

\section{UCAPAN TERIMA KASIH}

Kami mengucapkan terima kasih kepada RISTEK-BRIN yang telah memberikan dana penelitian sehingga kami dapat meyelesaikan penelitian ini dengan baik. Kami juga mengucapkan terima kasih kepada pihak Dinas Pariswisata dan Kebudayaan Provinsi Sulawesi Selatan yang telah memberikan informasi mengenai tempat-tempat wisata yang ada di provinsi Sulawesi Selatan.

\section{DAFTAR PUSTAKA}

[1] "Arti kata wisata - Kamus Besar Bahasa Indonesia (KBBI) Online." https://kbbi.web.id/wisata (accessed Sep. 08, 2020).

[2] J. J. Spillane, Ekonomi pariwisata: sejarah dan prosepeknya. Kanisius, 1991.

[3] I. G. B. R. U. MA SE ,. MMA, Pengantar Industri Pariwisata. 2016.

[4] "Website Resmi Dinas Pariwisata Dan KebudayaanProvinsi Sulawesi Selatan." http:/ / disbudpar.sulselprov.go.id/opd/index/ pariwisata (accessed Sep. 08, 2020).

[5] S. Sudin, Apa Itu Search Engine Marketing: Tinjuan Umum, Pondasi dan Sistem Lelang Ads. Sukri Sudin, 2019.

[6] J. Wright, Tour of Life: A Baptism and Confirmation Journey. St. Louis, Mo: Chalice Press, 2010.

[7] J. Karman, H. Mulyono, and A. T. Martadinata, Sistem Informasi Geografis Berbasis Android Studi Kasus Aplikasi SIG Pariwisata. Deepublish, 2019.

[8] I. C. Lawolo and A. P. Harianja, "Aplikasi Rekomendasi Objek Wisata Di Pulau Nias Dengan Algoritma Dijkstra Berbasis Android," J. Tek. Inform. UNIKA St. Thomas, vol. 2, no. 1, Art. no. 1, Jun. 2017, doi: 10.17605/jti.v2i1.38.

[9] I. Ilham, N. Norhikmah, and D. U. Z. Alamsyah, "Implementasi Web Service Dalam Pencarian Objek Wisata Berbasis Android," Semnasteknomedia Online, vol. 5, no. 1, Art. no. 1, Feb. 2017. 


\section{Rismayani, S Wahyuni, M Patasik, Iskandar \& S Asnany}

Komputika: Jurnal Sistem Komputer, Vol. 10, No. 1, April 2021

[10] I. N. S. Paliwahet and I. M. Sukarsa, “Pencarian Informasi Wisata Daerah Bali menggunakan Teknologi Chatbot," vol. 8, no. 3, p. 10, 2017.

[11] M. Rizal, "Perancangan Aplikasi Lokasi Wisata Kota Jakarta Menggunakan Algoritma Sequential Search Berbasis Android," J. Pilar Nusa Mandiri, vol. 13, no. 2, Art. no. 2, 2017.

[12] H. Kurniawan and M. R. Tanjung, "Sistem Informasi Geografis Objek Wisata Alam di Provinsi Sumatera Utara Berbasis Mobile Android," SISFOTENIKA, vol. 7, no. 1, Art. no. 1, Jan. 2017, doi: 10.30700/jst.v7i1.130.

[13] J. E. Prasetyo, I. B. K. Widiartha, and M. A. Albar, "Sistem Informasi Geografis Pencarian Lokasi Wisata Kuliner Terdekat di Kota Mataram Berbasis Website," J. Comput. Sci. Inform. Eng. J-Cosine, vol. 1, no. 1, Art. no. 1, 2017, doi: 10.29303/jcosine.v1i1.28.

[14] D. R. Anamisa, F. Umam, and A. Rachmad, "Sistem Informasi Pencarian Lokasi Wisata di Kabupaten Jember Berbasis Multimedia," Pros. SNATIKA, vol. 4, pp. 32-36, Dec. 2017.

[15] E. S. Astuti, N. Santoso, and I. D. Wijaya, "Sistem Informasi Pencarian dan Navigasi lokasi Wisata Bersejarah Kota Malang Berbasis Android," SEMNASKIT 2015, vol. 0, no. 0, Art. no. 0, Aug. 2018, Accessed: Sep. 06, 2020. [Online].

Available: https://publikasi.polije.ac.id/index.php/SEM NASKIT2015/article/view/1014.

[16] M. Ahmad, M. K. Safaruddin Hidayat AlIkhsan S. Kom, and M. K. Fitrah Satri S. Kom, "Pengembangan Aplikasi Pencarian Wisata Kuliner Kota Bogor Berbasis Range Harga Dan Metode Lbs (Location Base Servise) Pada Android," Inova-Tif, vol. 1, no. 1, Art. no. 1, Jun. 2018, Accessed: Sep. 06, 2020. [Online]. Available: http://ejournal.uikabogor.ac.id/index.php/INOVATIF/article/view/1327.

[17] K. Anam and O. D. Hartono, "Aplikasi Pemandu Pencarian Wisata Terdekat Berbasis GIS Android Dengan Algoritma Dijkstra," JSAKTI J. Sains Komput. Dan Inform., vol. 3, no. 1, Art. no. 1, Mar. 2019, doi: 10.30645/jsakti.v3i1.99.

[18] S. Santoso, I. Ilamsyah, and R. Abilaji, "Pandu Lokasi Wisata Kota Tangerang Dengan Sistem Informasi Geografis Berbasis Web," J. Sist. Inf. Dan Inform. Simika, vol. 2, no. 1, Art. no. 1, Feb. 2019.

[19] N. Suciyono, D. S. Anwar, and E. Setiawan, "Pencarian Wisata Kuliner Terdekat Dengan Menggunakan Metode LBS (Location Based Service) Berbasis Web Mobile Di Kota Tasikmalaya," J. VOI Voice Inform., vol. 8, no. 1,
Art. no. 1, Jan. 2019, Accessed: Sep. 08, 2020. [Online]. Available: https://voi.stmiktasikmalaya.ac.id/index.php/voi/article/view $/ 168$.

[20] F. Ariani, T. C. Adelia, Y. Aprilinda, and A. K. Puspa, “Temu Lampung Berasis Website Untuk Mempermudah Pencarian Tempat Wisata Serta Pemandu Wisata Di Lampung," Expert, vol. 9, no. 2, Art. no. 2, Dec. 2019, Accessed: Sep. 08, $2020 . \quad$ [Online]. Available: http://jurnal.ubl.ac.id/index.php/expert/articl e/view/1310.

[21] N. V. Y. R. Bani, A. F. Faisol, and F. X. Ariwibisono, "Aplikasi Pencarian Tempat Wisata Menggunakan Metode Location Based Service Pada Wilayah Kabupaten Timor Tengah Selatan Berbasis Android," Jati J. Mhs. Tek. Inform., vol. 4, no. 1, Art. no. 1, May 2020.

[22] Rismayani, "Penerapan Teknologi Google Maps API Pada Sistem Informasi Geografis Wisata Di Kabupaten Maros Berbasis Mobile | Request PDF," Pros. Temu Ilm. Peneliti Puslitbang Aptika IKP 2016 Badan Penelit. Dan Pengemb. SDM KOMINFO, 2016, Accessed: Sep. 08, 2020. [Online]. Available: https://www.researchgate.net/publication/326 466783_Penerapan_Teknologi_Google_Maps_A PI_Pada_Sistem_Informasi_Geografis_Wisata_ Di_Kabupaten_Maros_Berbasis_Mobile.

[23] Rismayani Rismayani and Ardimansyah Ardimansyah, "Aplikasi Berbasis Mobile untuk Pencarian Rute Angkutan Umum Kota Makassar Menggunakan Algoritma Depth First Search," Pekommas, vol. 18, no. 3, Dec. 2015, doi: 10.30818/jpkm.2015.1180303. 